\title{
Genesis of Two Educational Interaction Analysis Models in an Informal Educational Setting
}

\author{
Rodica Ailincai ${ }^{1, *}$, François-Xavier Bernard ${ }^{2}$, Annick Weil-Barais ${ }^{3}$ \\ ${ }^{1}$ EASTCO, University of French Polynesia, Tahiti,French Polynesia \\ ${ }^{2}$ EDA, Paris Descartes-Sorbonne University, Paris, France \\ ${ }^{3}$ LPPL, University of Angers, France \\ *Corresponding author: r.ailincai@gmail.com
}

Received July 27, 2014; Revised April 30, 2015; Accepted July 01, 2015

\begin{abstract}
In this article we present two educational interaction analysis models taking place in an informal learning environment (in particular scientific and technical activities outside of school). Both models were designed during research conducted within a museum setting in an interactive scientific and technical exhibition at the Cité des Sciences et de l'Industrie (Museum of Science and Industry) in Paris. The models presented here are consistent with the analysis of communicative interactions produced in any learning situation: the first model, the Media Square, is suitable for analyzing asymmetric dyadic exchanges (parent - child), while the second model, the KITLoK Model, is designed for analyzing polyadic situations, whether asymmetric or symmetric [tutor - student (s)]. The models intend to chart learning interactions in an educational situation which benefit from dual mediation: both human (the tutor, as a "human mediator") and instrumental (interactive museum tools, as a "technical mediator"). Both models will be discussed as regards the models of origin that inspired them. These models of origin will also be presented in the first part of the paper.
\end{abstract}

Keywords: interaction analysis, interactive learning, analysis models, Media Square Model, KITLoK Model

Cite This Article: Rodica Ailincai, François-Xavier Bernard, and Annick Weil-Barais, "Genesis of Two Educational Interaction Analysis Models in an Informal Educational Setting." American Journal of Educational Research, vol. 3, no. 7 (2015): 929-943. doi: 10.12691/education-3-7-18.

\section{Introduction}

The research reported in this article was conducted in museum exhibitions for young children in the Cité des Enfants (adventure playground for children) within the Cité des Sciences et de l'Industrie in Paris. The first study concerned the part of the exhibition dedicated to children from 3 to 5 years of age, whilst the second study was for children aged from 5 to 12 years. Both exhibitions feature an interactive environment in which pleasure is associated with the active discovery of science. It is recommended that children are accompanied by adults in order to make their visit more informative. The importance of interactions in the appropriation of scientific and technical knowledge by young children has been highlighted by various research in different disciplines: psychology, museology and didactics $([15,19,22,30])$.

The initial focus of the two studies was on the contribution of interactive museum tools designed for the discovery of science and technology. Our main issue was to determine whether this type of educational museum tools (some were media intended and aimed at giving a representation of reality, including the simulation software; others were artefacts used for facilitating access to some areas of knowledge, namely various trial and error games; or spaces reproducing ecosystems, namely the "butterfly greenhouse” or “anthill”), were cognitively suitable for young visitors. In order to answer this, we tried determining the impact of these tools under natural conditions. On the one hand, we observed how children accompanied by their parents used such educational tools during a visit to the museum and, on the other hand, how these tools were used by the pupils who were accompanied by a tutor (teacher, parent or other accompanying adult) during a school visit to the museum. This prompted two major questions: one concerning the cognitive contribution of these educational museum tools to the children who handle them, the other concerning the impact of the tutoring by adults accompanying the children whilst handling these tools.

In this article we will present two analysis models, which enabled us to chart the interactions around these museum tools:

- the first model, the Media Square [6], provides an analysis of parent/child interactions (dyadic interactions) around a color-mixing simulation software designed for young children of 3-5 years of age as part of a museum exhibition;

- the second model, the KITLoK model [3], analyzes interactions between a group of students and an accompanying adult (polyadic interactions) in a tropical butterfly greenhouse exhibition, which aimed 5-12 year olds. 
2. Research on Mediation in Scientific Exhibitions for Children in the Cité des Sciences et de l'Industrie in Paris

The models we present in this paper intend to chart learning interactions in an educational situation which benefit from dual mediation: both human (the tutor, as a "human mediator") and instrumental (the interactive educational museum tools, as a "technical mediator").

The concept of mediation, borrowed from social psychology, considers verbal interventions as a process of negotiation, not only as knowledge to be transmitted [41].

According to this conceptualization, any interaction that aims at learning, the tutor negotiates cognitive changes with learners [41]; thus, mediation can be considered as a process of co-construction of knowledge.
The exhibition we describe here has a role of a "mediator" acting as an intermediary between scientific knowledge and visitors. Guichard and Martinand [19] present the "media-exhibition" as a "conversation" between the visitor and the museum tool, introducing the idea of interaction and feedback between the visitor and the media, as opposed to the transmitter-receiver model.

The core component of these exhibitions for children is the parent-child interaction in a situation of discovery and experiential learning ("3-5 years" and "5-12 years"). The mediation model proposed by Paour [27] (see Figure 1) seems closest to the discovery and experiential learning situation in the exhibition for young children of 3 to 5 years of age. The author, in his research in cognitive education, has taken into consideration both human and instrumental mediation.

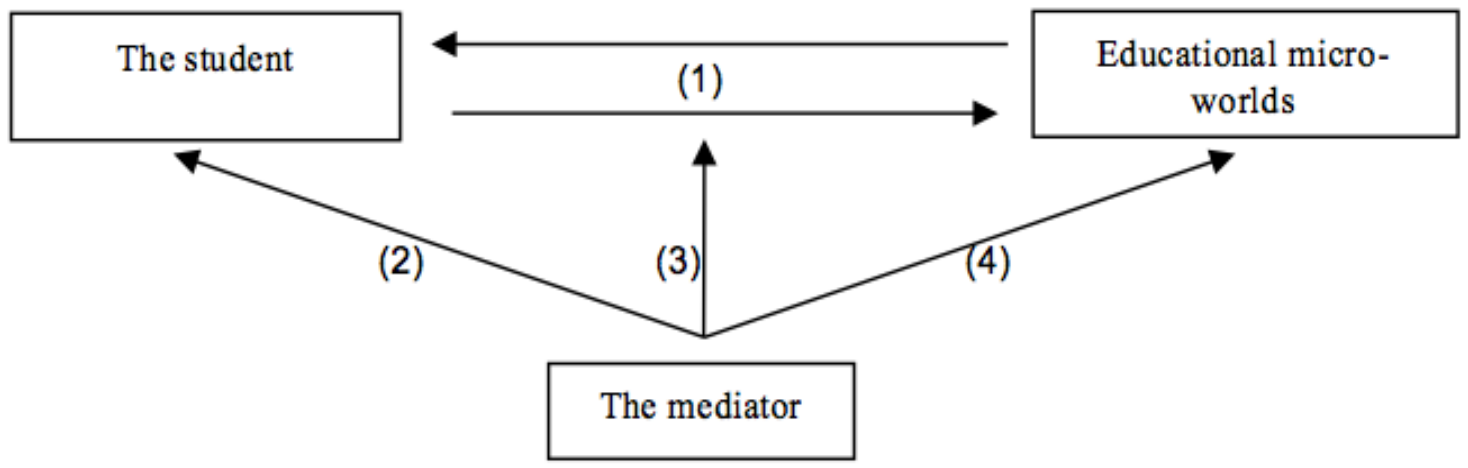

Figure 1. Diagram by Paour, 1988

In this diagram, Paour [27] voluntarily placed the position of human mediator off-centre so that it did not come between the subject and objects, since "mediation should not display or be a substitute for the proper action of the subject shown by the arrow (1) (...) Arrows (2), (3) and (4) signify the omnipresence of the mediator...)"([27] p.50).

The "micro-world" (also called the interactive museum tools) is a hardware device upon which the subject acts and through which the subject gives his/her own answer. In short, the micro-world has the function of a technical mediator. Paour [27] specifies that these micro-worlds presented in these exhibitions, which are means for taking action, also have thought-provoking aspects for creating social interactions.

According to subsequent theoretical positions of Paour [28], these two mediations [through a technical (mediator (Mt micro-world) and through human mediation (Hm human mediator) are designed as peripheral elements of the subject's functioning and are situated within the environment.

These two types of mediation coexist in the exhibitions in the Cité des Enfants: on the one side, there are educational museum tools that constitute the technical mediator between the knowledge (savoir savant) and the child. These tools attract and retain the child's attention by enabling him/her to develop an approach and to access knowledge adapted to his/her own development and interests. On the other side, there is human mediation, adult tutors who facilitate and guide the use of the educational tools.

\subsection{Research on Human Mediation}

Since the establishment of the Cité des Enfants at the Cité des Sciences et de l'Industrie in Paris, many studies have analyzed the behavior of children with these educational tools in a museum setting, whether alone or accompanied by (an) adult(s). The results show that a child left alone without (an) adult(s) may have various reactions. S/he can play with the tool then act upon it for a short time without taking time to understand its operation, but can also take the time to reflect on the effects that are produced by his or her own actions with the tool.

In the studies based solely on observations, without interviews or testing after the activity, it is difficult to assess the understanding of the child. It is therefore important to know how to observe different phenomena and changes that will be highlighted through the child's activity with these tools. Children who take the time to observe are those who interact with adults ([9,17,25,39,40]). Furthermore, in the Cité des Enfants the exhibition, which cater for children aged between 3-5 years, adult-child interactions occur most often in the form of a supervisory relationship [1]. The visit is mostly carried out for educational purposes. In such visits the supervision provided by parents depends on parents' perception of education. ([2,18]). As such, the issue is to know what forms of supervisory relationships parents have with their children. Based on our previous work, in Table 1 we summarize the studies conducted at the Cité des Enfants on relations between accompanying adults and children during visits. 
Table 1. Summary of studies on human mediation at the Cité des Enfants at the Cité des Sciences et de l'Industrie in Paris

\begin{tabular}{|c|c|c|}
\hline & Authors and name of the study & Type of human mediation \\
\hline \multirow{2}{*}{ 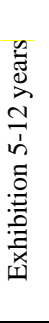 } & $\begin{array}{l}\text { Weil-Barais \& Piani } 1993 \text { [39] } \\
\text { "Adult-child exchanges at the Cité des } \\
\text { Enfants" }\end{array}$ & $\begin{array}{l}\text { Disjointed type (each has a monologue type of intervention); } \\
\text { Complementary type (one person's intervention lead to the production of separate interventions from } \\
\text { the other); } \\
\text { Imitative type (interventions of one are taken up by the other). }\end{array}$ \\
\hline & $\begin{array}{l}\text { Weil-Barais \& Piani, } 1995 \text { [40] } \\
\text { "The conditions of coeducation for } \\
\text { visitors coming spontaneously to the } \\
\text { "Cité des Enfants" }\end{array}$ & $\begin{array}{l}\text { Complementary type with predominance of the parent (in this type of intervention parents function as } \\
\text { a supervisor especially when parents understand how the tools operate before the child does); } \\
\text { Complementary type-with predominance of the child (this type of intervention occurs more when the } \\
\text { parent requests an explanation); } \\
\text { Confrontation type (who is rarely seen)this concerns exchanges in the type of confrontation of } \\
\text { viewpoints. }\end{array}$ \\
\hline \multirow[t]{2}{*}{ 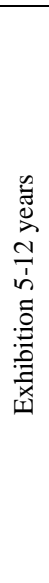 } & $\begin{array}{c}\text { Chaumier, Casanova Habib, } 1995 \text { [9] } \\
\text { "Accompanying adults of the Cité des } \\
\text { Enfants" }\end{array}$ & $\begin{array}{l}\text { Substitute visit, the adult decides everything and the child having to follow and obey: , choosethe } \\
\text { games, controls the actions. The adult either deems the child incapable of initiative or replaces the } \\
\text { child taking over the visit. } \\
\text { Solo visit, parents and children discover the exhibition separately, parents do not show concern for the } \\
\text { child's activities; the child is left to his/her own devices, either because s/he wishes to be autonomous, } \\
\text { or the adult loses interest, feels overwhelmed, or is involved in other things; } \\
\text { Companion visit, parents impart knowledge through explanation in a quiet moment and remain close } \\
\text { to the child; } \\
\text { Non-directive pedagogy, the adult intervenes to explain, to answer questions, to further develop a } \\
\text { subject; } \\
\text { Directive pedagogy, the aim of which is to instill knowledge in the child. } \\
\text { Devouring visit, characteristic of a first visit, superficial approach to the themes and a desire to } \\
\text { discover everything. }\end{array}$ \\
\hline & $\begin{array}{l}\text { Samuels-Pitzini et Cauzinille- } \\
\text { Marmeche, } 1996 \text { [37], "Interactivity } \\
\text { and human interactions: which at } \\
\text { which moment?" }\end{array}$ & $\begin{array}{l}\text { Parents from the Paris region: } \\
\text { - carry out the most detailed actions themselves ; } \\
\text { - explain the least ; } \\
\text { - spend the least time on the educational tools ; } \\
\text { - ask very few questions and provide very few answers. }\end{array}$ \\
\hline \multirow{3}{*}{ 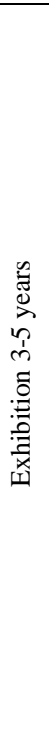 } & $\begin{array}{l}\text { Romano, } 1999 \text { [36] “The area for 3-5 } \\
\text { year olds in the Cité des Enfants : } \\
\text { visiting behavior and the viewpoints } \\
\text { of a sample of child and their parents } \\
\text { on the exhibition” }\end{array}$ & $\begin{array}{l}\text { The adult has the role of a guide : } \\
\text { - helping the child to go around the exhibition, } \\
\text { - choosing the activities s/he wants to do, } \\
\text { - verbalizing the written instructions that the child cannot understand, } \\
\text { - explaining what the child sees. }\end{array}$ \\
\hline & Ailincai, 2005 [1,2] & $\begin{array}{l}\text { Directional interactive style: the parent imposes the approach for proceeding, delivers know-how, } \\
\text { clarifies the procedure to follow and is concerned about the child's success and the attention that the } \\
\text { child brings to the activity. } \\
\text { Suggestive interactive style: the parent asks the child about the actions to take, encourages the child to } \\
\text { make connections, to produce explanations. The parent makes the child active, rephrases his/her } \\
\text { questions, outlines the level of success, seeks the opinion of the child, asks to be advised, helped. } \\
\text { Empowering interactive style: the parent leaves the child to discover, supports him/her in successive } \\
\text { tests promoting learning by trial and error. The parent simply observes the child busy with a task, } \\
\text { his/her presence next to the child being an implied assessment, whose positive character emanates } \\
\text { from the permission given to the child to continue his activity. Disjointed operating style: typical of } \\
\text { an individualistic approach, adults and children each have their own mode of intervention in the } \\
\text { keeping. }\end{array}$ \\
\hline & Bernard, 2006 [6] & $\begin{array}{l}\text { The impact of the use of the simulation tool (application), displayed in scientific exhibitions, depends } \\
\text { on the previous experience of the child, as well as on the tutoring quality of the adult accompanying } \\
\text { the child. } \\
\text { Tutoring can only has an impact on the child after reaching a certain ages regards the field of } \\
\text { knowledge in question (a computer simulator allowing mixtures of paints), and seems essentially } \\
\text { connected to the informative content of the exchanges. }\end{array}$ \\
\hline
\end{tabular}

\subsection{Studies on Instrumental Mediation}

Few studies have examined instrumental mediation in aforementioned exhibitions. We present some here.

A study by the Observatoire des publics (Public Observatory) of the Cité des Sciences [10] evaluated the ensemble of the museum exhibition's tools as follows:

- the visibility of the tools' purpose by visitors (easy or difficult to locate),

- the actual use of the tools compared to the initial objective set by the designers - actions to achieve the goal, or to work around it,

- the adaptation of the ergonomics of the tools or children, the frequency of use of the "machine",

- various remarks made by visitors about handling the tools.

This assessment contributed to the improvement of some museum tools.

Another study, conducted by Romano [36], aimed to support the renewal project of the Cité des Enfants, particularly the exhibition space for 3-5 year olds. In addition to observations about the behavior of the accompanying adults, this study also looked at certain characteristics of educational museum tools. The following were observed in particular:

- the preferences of children and parents, as well as the relevance of some educational museum tools from the parents' viewpoint: equipment requiring handling, trial and error and less observation were appreciated;

- the organization of the visit according to the "itinerary" chosen by visitors: the "itinerary" suggested by the staging of the exhibition was respected by most visitors on their visit; during subsequent visits, "returning" visitors or members of the museum started with the equipment they preferred;

- an opinion on the accessibility of the exhibition for children under 3 years of age (the ergonomics of some machines enabled younger children to enjoy the exhibition).

We also refer to the work of Guichard ([16,19]). This researcher developed the concept of media impact in order 
to provide exhibition designers with a decision-support tool: "it allows us to anticipate the results of media outputs and adapt those targeted" ([19] p. 168). Identifying the impacts on visitors will thus provide a basis for judgment leading to, and justifying, the decisiontaking of exhibition designers. We will focus mainly here on the impacts of a cognitive nature and the processes leading to them. The main difficulty lies in assessing the impacts of the educational museum tools (which are called as media tools) and in determining the measurement criteria. For this, it is necessary to define observable and operational, impact indicators that we will identify with the help of specific tools designed for this purpose drawn from different research areas: observation, testing, interviews, so forth. Guichard ([16], p. 183) has listed the most appropriate instruments, depending on the impact to estimate (see Table 2).

Table 2. Examples of tools estimating the media impact[16]

\begin{tabular}{|l|l|}
\hline Estimate of media impact & Tools used \\
\hline Analysis of effects & Check-list, observation, semi-structured interviews \\
\hline Media's capacity to attract & Observation, counting \\
\hline Media's capacity to retain & Measuring time spent in front of the media or a page of the media \\
\hline Global impact & Semi-structured interviews \\
\hline User satisfaction & Observations, interview \\
\hline Understanding, memorizing speeches & Pre- and post-tests \\
\hline Change in behavior & Comparative approach of attitudes in front of the media \\
\hline Comparison of different media items & Observation of non-verbal behavior, then interviews, a "hit-parade” of items \\
\hline Use of interfaces & Observation on the post \\
\hline Orientation behavior in the media & Observation on the post \\
\hline Exploratory strategies and tactics of the device & Observation, then semi-structured interview \\
\hline
\end{tabular}

In addition to the concept of media impact, Guichard developed the concept of "science media".

According to this author, science media characterizes the use of all media (also known as the media field) in popular science: architecture, interactive handling of exhibits, objects, models, pictures, text, signs, audiovisual material, software, multimedia, books, documents and materials related to exhibitions, etc.

All of these forms of media have an important place in the interactions between visitors, constituting a "technical mediator" between knowledge and intentions of designers and visitors.

\section{Models Representing the Educational Situation in the Museum and Their Sources of Inspiration}

The aforementioned research confirms the important role played by the adult with the child during the visit. The approach taken by children in the exhibition is therefore based on a dual relationship, interaction with adults and interactivity with educational museum tools. This operation is often symbolized in studies on exhibitions by a ternary system that defines the learning situation or the context in which knowledge is brought into play. Studies conducted at the Cité des Enfants, including Guichard's research, represent mediation in a triangular manner (see Figure 2).

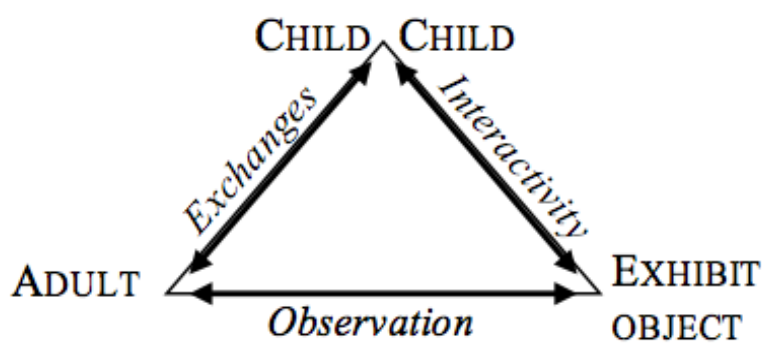

Figure 2. Model of interaction in the exhibition [18]
This depiction is inspired by the work of Houssaye in the school context and his classic educational triangle featuring the student-skills-teacher trio in the learningteaching-training relationship [20]. The ternary model of pedagogical understanding of Jean Houssaye ([20,21]) seems to position itself as an advance on the binary model of traditional Teacher-Knowledge pedagogy which favored, according to him, the "teaching" process focusing on content and forgetting the learner (see Figure 3).

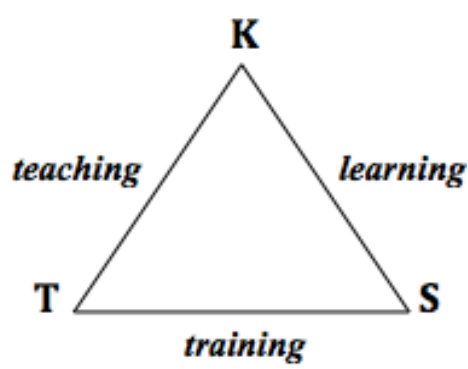

Figure 3. The Pedagogical Triangle

According to Houssaye, the three vertices of this ternary model define the space of any pedagogical act: the Teacher (who transmits or teaches the knowledge), the Student (who acquires knowledge, expertise and knowhow, knowing how to act, how to be...) and the Knowledge (the subject, the syllabus to teach...).

The sides of this triangle characterize the relationship between the three parties involved in the pedagogical situation. According to Houssaye, the relationship between these three agents is characterized by a dominant binary of two agents at the expense of the third. For example, the "learning" process is characterized by the privileged relationship between the Student (S) and the Knowledge (K), which the Teacher (T) is omitted from; in the "teaching" process, the Student (S) is omitted; whilst on the "training" axis, the Knowledge $(\mathrm{K})$ is set aside". The relationship between the three is always truncated: and we never come across a triadic "K-T-S" situation.

Although the main criticism directed at this model focuses on the non-contextualization of the pedagogical 
act in a culture at a given time, today we can rightly question the absence of the instrument from this model. Indeed, the place of the instrument in the interaction between the various components of the educational situation and the structural effects of the activity related to the use of artifacts are suggested by many authors.

As Guichard applies this model to the interactive museum situation, it retains the triangulation by replacing "knowledge" with "exhibit feature". We can assume that the author brings together under this label the knowledge and the instrument ("media tool") which mediate this same knowledge. Guichard [18] shows as an interchange the link between the scientific words ("learned wisdom") and the educational museum tools (technical mediator) (see Figure 4).

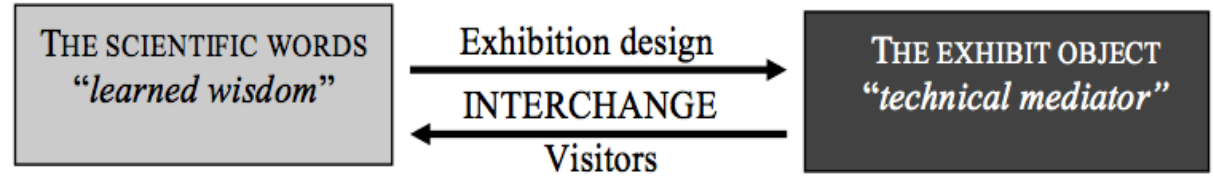

Figure 4. Media interchange, Guichard, 1998 [18]

This interchange is based on knowledge of the child's reference framework, their interests and their questions. In this sense, when the Cité des Enfants was being established, one of the main objectives was to consider the actions of children and their obstacles to understanding the phenomena and objects presented. It is from their own knowledge and based on their own questioning and with their own attitudes that visitors (parent and child) discover the exhibition. Several studies have shown the importance of taking into account the actions and practices of visitors because they challenge their ideas and interpretation of phenomena through their own frame of reference $([11,12,15,24,26])$. All these factors were taken into account both for the selection of topics, knowledge to be transmitted (to transfer), as well as for defining the ergonomics of the exhibition objects. This reflection is generalized for all educational museum tools (models, software, panels, interactive tools, etc.). The idea concerning cognitive ergonomics has been the focal point in Rabardel's research ([31,32,33]).

Rabardel defined the concept of artifact as a material or symbolic man-made object. He distinguished an artifact from an instrument. For him, "instruments are not conceptually neutral; they contain a "world view" and more or less impose themselves onto their users, and thus influence the development of their skills.” ([33], p. 213)

According to Rabardel, an artifact constitutes only the neutral or universal part of an instrument. This part is relatively independent of how the user uses the instrument, since an artifact is not a result of spontaneous creation but the result of a completed activity. The artifact thus includes an added anticipatory function, whether it was explicitly or implicitly added by the designer. In short, the instrument can be used in many diverse ways independently of the intended use by the designer.

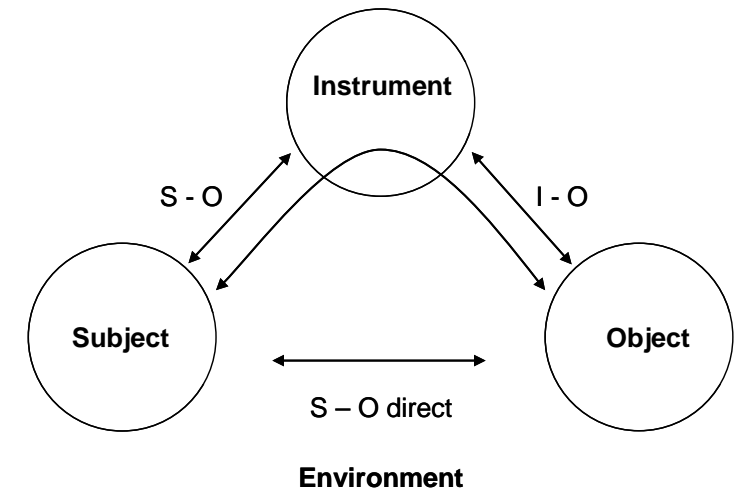

Figure 5. IAS model [33]
On the basis of this definition, the author proposed a model of Instrument Mediated Activity Situations, called IAS (see Figure 5).

The three poles involved in the use of an instrument are: 1) the subject (user, worker, operator, agent...); 2) the instrument (tool, machine, system, utensil, product...); 3) the object towards which the action is targeted, (subject, object of the activity or work, or another topic...).

Added to all the direct interactions between the subject and the object (S-Od), the IAS model takes into account interactions between the subject and the instrument (S-I), interactions between the instrument and the object upon which it acts (I-O) and interactions between the subject and the object mediated by the instrument (S-Om). Finally, each pole and each interaction interact with each other and are influenced by: a) other elements of the environment in which they are immersed; b) under specific conditions linked to the activity of the subject.

This dimension of Rabardel's work is of particular interest to us since it can be found in all types of learning environments (classroom, family, museum settings, etc.). Notably in a museum context the designer of these educational tools, imagine the use of the artifact in question as regards the objectives he originally intended. Moreover, the technical object in itself does not always determine the instrument, which leads to possible diversions that Rabardel referred to as "catachreses", indicators which denote "the gap between the expected and the reality in the use of artifacts” ([33,34]).

This situation is extremely interesting for the analysis of interactions in learning: on the one hand, the instrument used in a learning situation may be redirected; on the other hand, the instrument may generate questions by children and lead to other types of knowledge (what we call "other Knowledge”, see the KITLoK model which we describe later on). This brief overview of the work of Rabardel and his ternary modeling of the cognitive approach for instrumented tasks shows that the appropriation process of technical objects is not immediate or intuitive as is often thought, but actually requires a genuine instrumental genesis. This is why it seems necessary for us to effectively chart the relations that occur during the usage of an educational museum tool: a) to distinguish the instrument (i.e. educational museum tool) from the action that one can produce with that instrument. Here the action constitutes the means to access knowledge which is not necessarily the intended aim of the conceptor of the instrument. This reflection of Rabardel leads us to reconsider Houssaye's and Guichard's triadic models in 
order to propose a model that takes into account the interaction between the elements mentioned: the child, the knowledge and the two "mediators": accompanying adult ("human mediator") and the instrument ("technical mediator”).

\section{Two New Models of Analysis of Interactions in an Informal Educational Context}

The models that we have developed and will present in this part of the article describe in detail the interplay between the learner, tutor and educational museum tools, whilst being primarily concerned with the place of the targeted knowledge: a) which mediation is deployed by the accompanying adult and b) how the instrument used in order to facilitate the child's learning.

As far as we are aware, few studies have shown real interest in the analysis of learning interactions and knowledge acquisition in "educational museum visits" (compared to a "leisure trip" to the museum). This lack of interest in educational museum exhibitions can be explained as follows: a) according to some researchers these educational museum activities are good at generating interest and motivation, encouraging curiosity and critical thinking and food for thought but not necessarily generate learning (Vivet 1991; Guichard, etc.); b) the limitation related to visiting conditions and especially to time constraints (one and a half hours per visit) impose short-term handling time and the exploration of tools is therefore often incomplete.

In our view, the issue of learning in a museum setting should be undertaken according to a particular context in which "knowledge" is presented and tackled with the visitors:

- on the one hand, this concerns the original intentions of the visitors, in particular the intention of a "leisure trip" (generally family outings on weekends) or a "pedagogical visit" ("school outings" and sometimes family visits in the case of a personal investment in the child's education);

- on the other hand, it is necessary to take into consideration the museum context, especially the concept of "science media” developed by Guichard [19]. Learning can happen through understanding, grasping, observing, discovering, acquiring, testing, comparing, classifying, associating, confronting, evaluating, reproducing, playing and so forth.

It is under these terms that we have raised the question of learning within the museum context and not through a systematic comparison with academic learning (which is often considered in a reductionist approach limited to accumulating intellectual content). This tendency to consider learning only in reference to academic requirements is natural as "learning is inextricably linked to school unconsciously” ([13], p. 10). Yet the act of learning is a complex process which occurs in many different forms [14], in particular in a place such as a scientific exhibition, with three-dimensional media which visitors browse through physically and intellectually, alone or with others, to experience situations that will trigger sometimes implicit multi-sensory investigations.

\subsection{The Media Square}

The first model was proposed by one of the authors of this article, Bernard, in 2006, as part of his research that was carried out in an exhibition for young children (a "3-5 years” group) at the Cité des Sciences et de l'Industrie in Paris.

Bernard proposes [6] a detailed analysis model of learning interactions around a color-mixing software: on the one hand relying on the instrumental approach proposed by Rabardel [33] (for which any instrument consists of an artifact, a neutral social object, and its patterns of use specific to each user) and, on the other hand, basing itself on the concepts of science media proposed by Guichard.

Within this context, his objective was to report on the impact of this media device (the color-mixing software: "Draw with your finger"), on the acquisition of knowledge of young children, whilst taking into account the educational scaffolding provided by parents.

\subsubsection{Presentation of the Media Device}

The exhibition element "Draw with your finger" consists of a computer monitor with a touch screen which is protected by a Plexiglas cover (see Figure 6). No other element is accessible to the visitor; the central processing unit (CPU), keyboard and mouse are inside the cabinet that supports the monitor. There are no speakers and the game does not broadcast any sound. Small stools suitable for all children are located in front of the device.

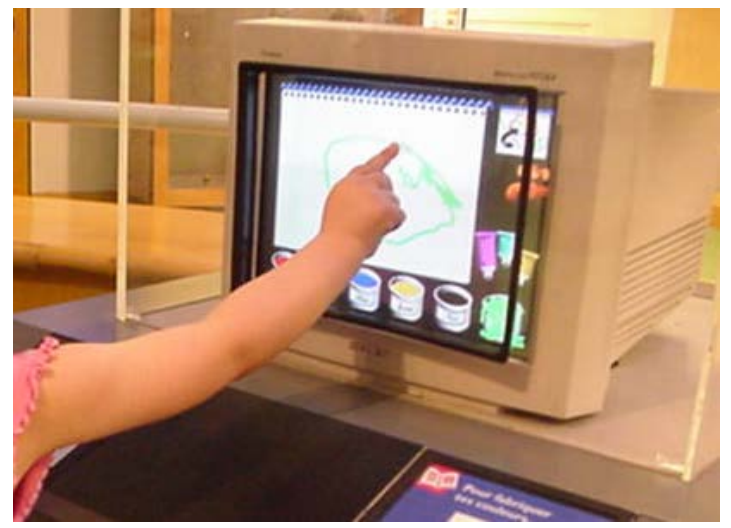

Figure 6. Item of the exhibition "Draw with your finger", Cité des Sciences et de l'Industrie, 2006.

On the tablet in front of the monitor are two short written instructions. The first encourages handling by indicating, "Draw on the screen with your finger". The instruction states the following clarification: "To make your colors... touch the tubes of paint on the screen. The colors will mix in the jar below". Although these phrases are obviously intended for the child, they will be read only by the parents, on the condition that they pay attention to them and they are French speakers. Another implicit indication is provided to all users, children and parents, through the screen. When not in use for more than 20 seconds, a program will loop automatically. Colorful designs form on the screen aim to highlight the different possibilities of the game but also to attract the visitors to the device.

When a visitor touches the screen, the animation stops and leaves the field open (see Figure 7). 


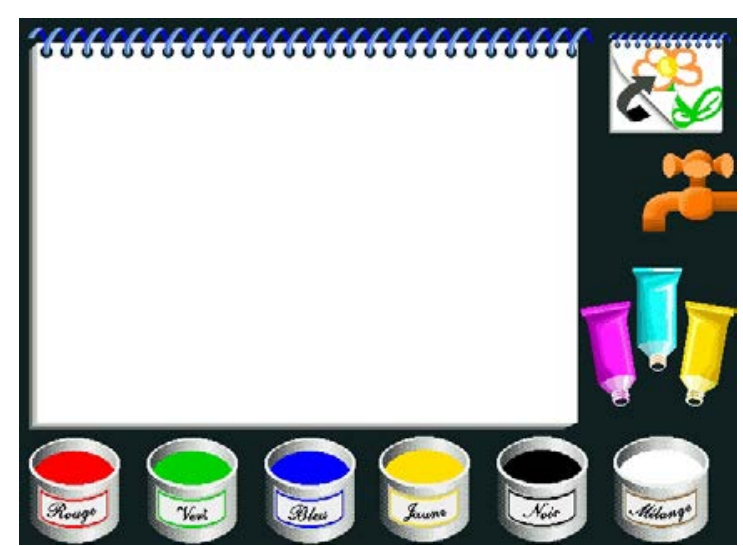

Figure 7. Screen shot of the game "Draw with your finger", Csi

The interface presents the children with the image of a spiral notebook on which they will carry out their drawings. They have red, green, blue, yellow and black cans of paint that they will be able to use directly, as well as a mixing pot with which they can create their own colors. To make their mixtures, children must use three tubes of primary color: cyan, magenta and yellow. The resulting color depends on the chosen proportions. On the right of the screen, the tap is used to "clean" the pot in order to create new mixtures.

When the child presses on a pot to select a color, the pot overflows and remains like this until the child selects another color. The arrow on the top right of the screen allows the child to erase the drawing and display a new blank page.

\subsubsection{The Analysis Model}

This analysis model is anchored in Vygotsky's theory [38]. Vygotsky places the instrument and language which are the fundamental aspects of cultural behavior for him, at the center of the formation and functioning of higher mental processes in the individual. This instrumental perspective has exerted major influence in the analysis of relationships between artifacts and techniques.

Let us recall here that Bernard's research aimed to determine the cognitive impact of a museum device (an educational museum tool) in a science exhibition for young children aged from 3 to 5 years (the computer simulator presented previously) in order to measure the relative weight of the different factors likely to play a role, on both inter- and intra-cognitive levels. In his research Bernard (2006) mainly focused on the function related to color mixing. According to Rabardel [33], exploited the media device; he assigned it with an aim that was not specifically there initially: becoming aware of the transformation process inherent in the mixing process. In his research work Bernard (2006) exploited the media device with an aim which was not the initial objective or intention of the conceptor of the computer software application he used. In Bernard's research we clearly observe the conceptualization offered by Rabardel as regards instrumentalization of an artifact (as we mentioned earlier). In his research Bernard was interested in color mixing which was not the intended aim of the software application which is a good example of Rabardel's concept.

The study was carried out in a natural museum visiting setting in which parents were asked to accompany their children throughout the activity. A sample of 25 children was sought: within this sample, one group of children benefited from parental supervision ("Parent Group"), whilst an expert mediator ("group mediator") accompanied the other group. In this study, we will refer only to the "parent group". From the observation of parents and with regard to the guidance of the expert tutor, the author attempted to determine the impact of the simulator under natural conditions of use.

In order to generate a model of a learning situation in a museum setting (which the author called media situation), Bernard dissociated the 'the tool as an instrument' from 'the tool as technical mediator' to analyze learning interactions involving between: the student, the instrument, the tutor, and the knowledge. He called this four-pole exchange model as “Media Square Model” (see Figure 8).

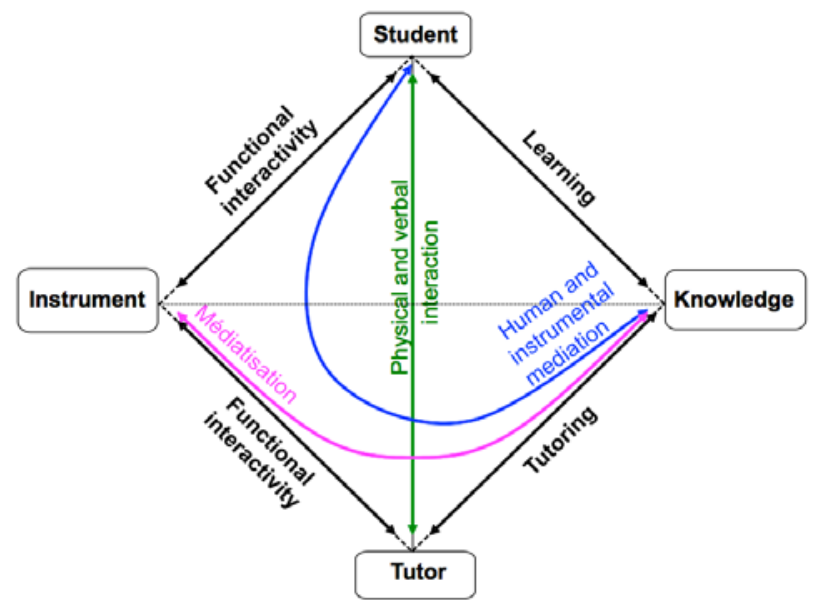

Figure 8. The Media Square (Bernard, 2006)

The characterization of each dyadic interaction during the operation of the computer simulator, checked against the results obtained by the children, enabled him to identify the different elements that may be decisive in terms of impact with children.

As shown in Figure 4, the Media Square reflects all interactions that may arise between the different partners in a media situation: The Media Square is complete.

However, during the media situation, the interaction between the four poles (which the author calls the “quaternary relationship”)) may not always be constantly in interaction with one another: in some cases one or even two poles may be absent. The Square will then be temporarily truncated and reduced to a tripolar or even bipolar relationship. In his thesis, the author describes the different possible configurations of the media situation together with the associated coding grid (Ibid., p. 87-90).

As an example, we show here two configurations of the truncated Media Square (see Figure 9 and Figure 10).

Example 1: The "instrument” pole disappears (see Figure 9).

In the example shown in Figure 9, the "instrument" pole disappears: when the parent is part of an educational process, the parent will guide the child in the activity.

It may then be necessary to temporarily suspend the child's interactive relationship with the instrument, or delay it at the beginning of activity, in order to engage in a discussion with the child and lead him or her to reflect on different aspects of the content of the knowledge involved. The instrument thus steps aside from the media situation in which the only mediation will be provided by the adult. 


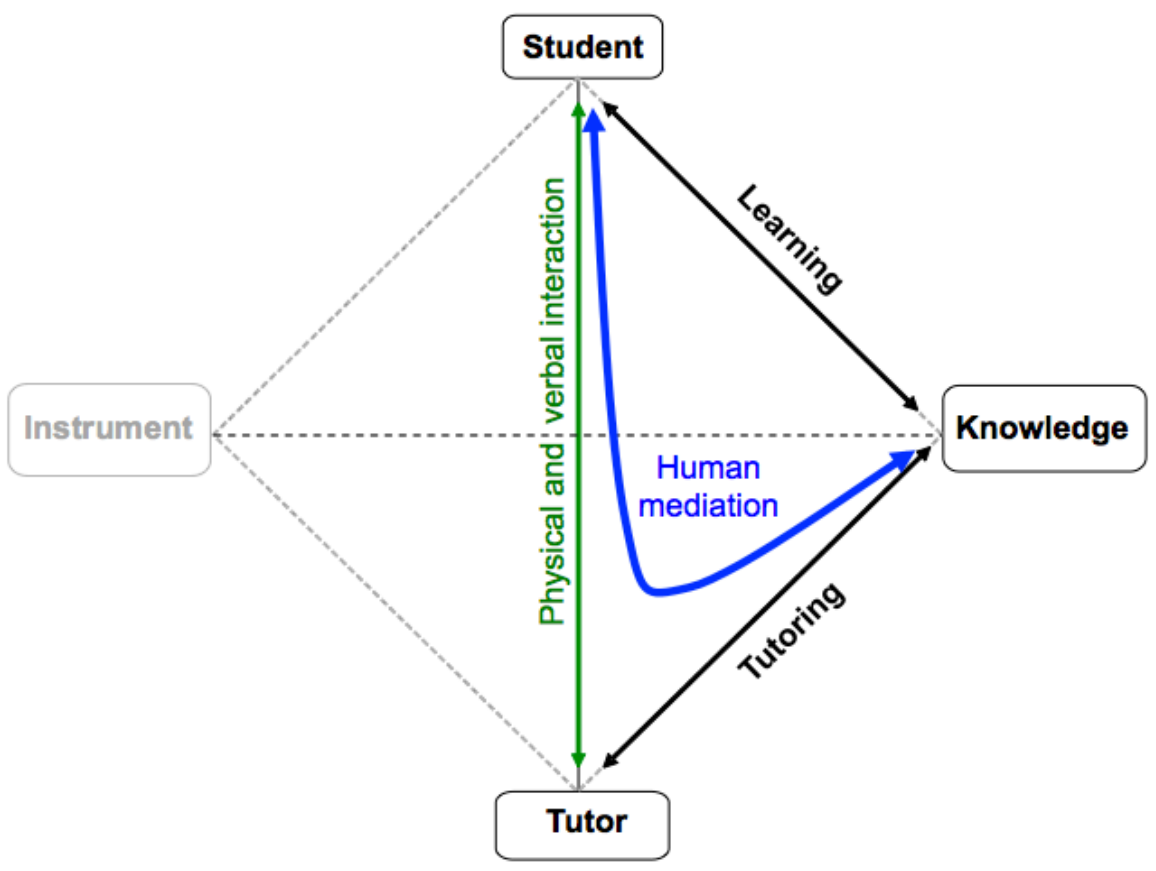

Figure 9. Truncated Media Square (absence of the Instrument)

Example 2: The “adult” pole disappears (see Figure 10)

In Example 2 (see Figure 10), the physical presence of a parent at the child's side in no way assumes the type of an intervention that the former will have with the latter. Adults may sometimes be present only for accompanying or monitoring purposes, without getting involved in the child's activity. On the contrary, the parent may pay attention to the child's activity but deliberately exclude him or herself from the media situation in order to let the child discover it alone and handle it freely. The parent may also be "invited" by the child to leave the situation. In all cases, whether momentarily or for the duration of the activity, the child is then alone with the instrument and knowledge. In such cases human mediation ensured by the adult disappears and knowledge is mediated only by the instrument.

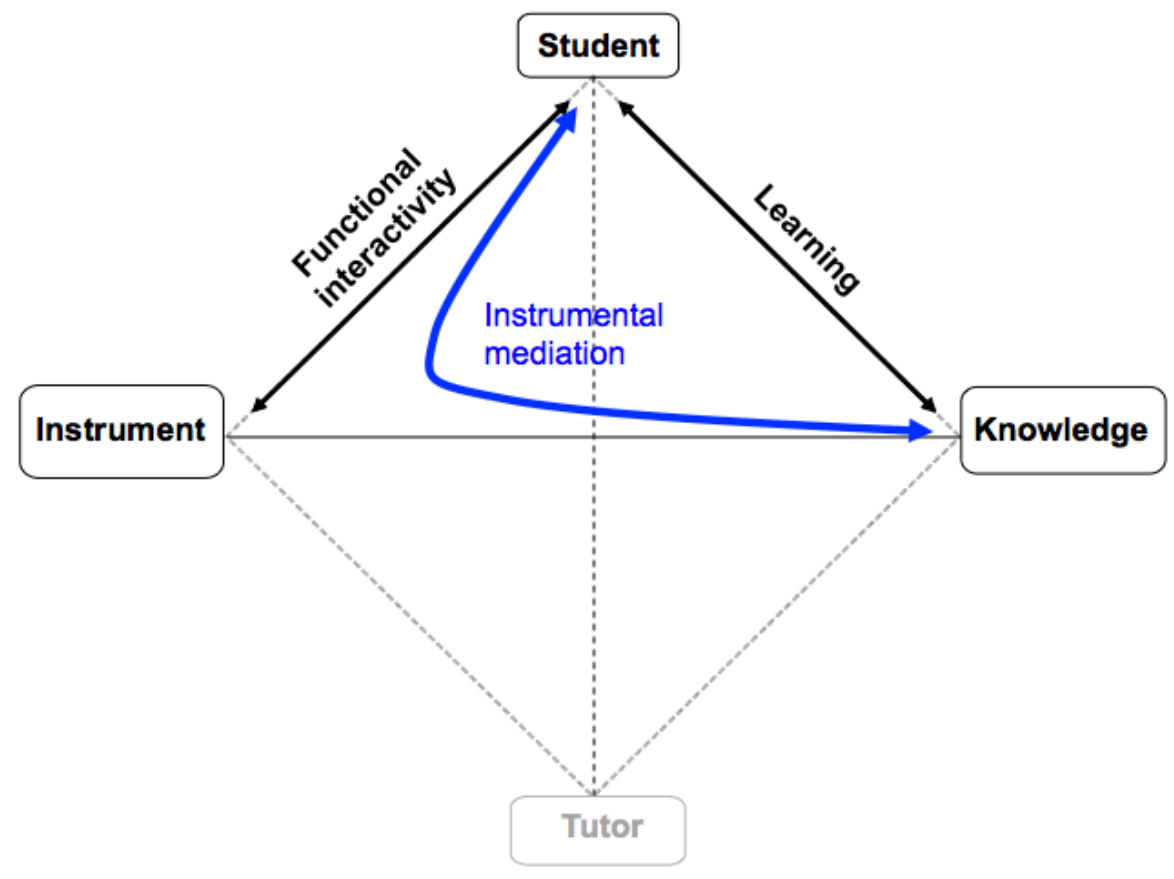

Figure 10. Truncated Media Square (absence of the adult)

The absence of certain poles during the activity brings to mind Houssaye's Pedagogical Triangle (suggesting that the relationship between the three interactants of the pedagogical situation is still truncated).However, unlike the latter model, the Media Square Model can fully be functional with all four poles operating equally well together (which is the case of quaternary relations).
The coding grid, based on the Media Square, lists all the possibilities broken down per model. The author lists 14 such possibilities. We present here various examples of codes for the three categories:

Quaternary relations; Example:

QKTLI1 / QKTLI2 / QKTLI3 (Q for quaternary, K for Knowledge, $\mathrm{T}$ for Tutor, $\mathrm{L}$ for Learner -or Student-, and I 
for Instrument); the numbers indicate who performs the task: 1 = the student performs the task; $2=$ both the tutor and the student, perform the task together; $3=$ the tutor performs the task.

Ternary relations; Example:

TTLI1 / TTLI2 / TTLI3, (T for Ternary, T for Tutor, L for Learner -or Student, and I for Instrument); 1 = the student manipulates the instrument; 2 = both the tutor and the student, manipulates the instrument together; $3=$ the tutor manipulates the instrument.

TKTL (T for Ternary, K for Knowledge, T for Tutor, L for Learner);

TKTI ( $\mathrm{T}$ for Ternary, $\mathrm{K}$ for Knowledge, $\mathrm{T}$ for Tutor, and I for Instrument);

TKLI ( $\mathrm{T}$ for Ternary, $\mathrm{K}$ for Knowledge, $\mathrm{L}$ for Learner and I for Instrument).

Binary relations; Example:

BKT (B for Binary, K for Knowledge, T for Tutor); BKL (B for Binary, K for Knowledge, L for Learner); BTI (B for Binary, T for Tutor and I for Instrument); BLI (B for Binary, L for Learner and I for Instrument); BTL (B for Binary, T for Tutor and L for Learner).

In concrete terms, in order to use this model, the author filmed each dyad (parent-child- human interaction). The recorded exchanges were then transcribed taking into account each pair's verbal and non-verbal interventions (gestures, manipulations, expressions, etc.). Analysis of the transcriptions consisted of breaking down the corpus into sequences centered on the same task [22], followed by coding of the sequences using one of the configurations of the Media Square (see Figure 11).

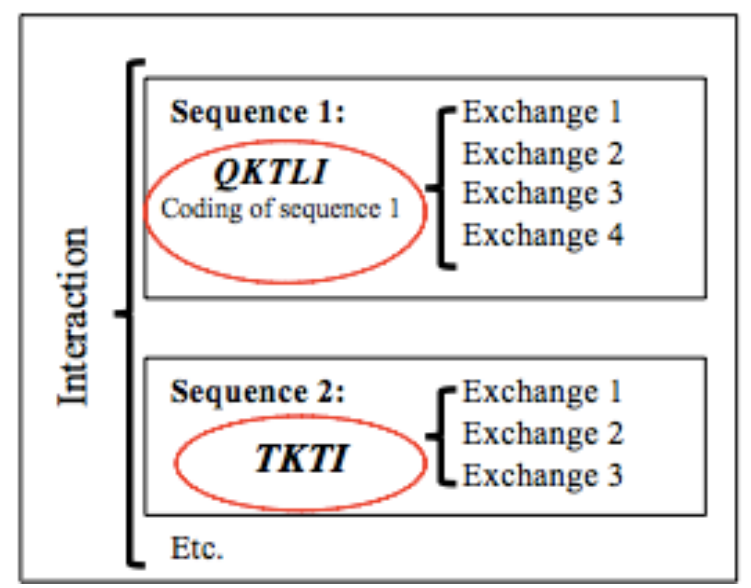

Figure 11. Diagram showing the breaking down and coding of the corpus

Sequences are defined as a block of exchanges connected by a high degree of semantic and/or pragmatic consistency. The sequences indicate the tasks examined in the discovery of the mechanism: the more varied the tasks is, the more one can consider that the mechanism has been thoroughly tackled in its different forms.

In each table, a sequence is identified by a code; inside this sequence there is a number indicating the order of exchanges; and there are also the time references indicated in seconds. From this information, the author has charted the evolution of each interaction over the duration of the activity (see Figure 12).

Each chart was drawn up from the sequences constituting the interaction which they characterize. The axes of the diagram represent:
- on the vertical axis we see, fourteen model configurations in the following order, from top to bottom: quaternary, ternary and binary;

- on the $\mathrm{X}$-axis we see, the time in seconds of interaction.

In the diagram, each sequence is represented by a horizontal line which is proportional to its length of duration (which is situated next to the line of the code it represents). The object on which the sequence of operations is based (i.e. knowledge, drawing, instrument) is identified by a shade of gray color code.

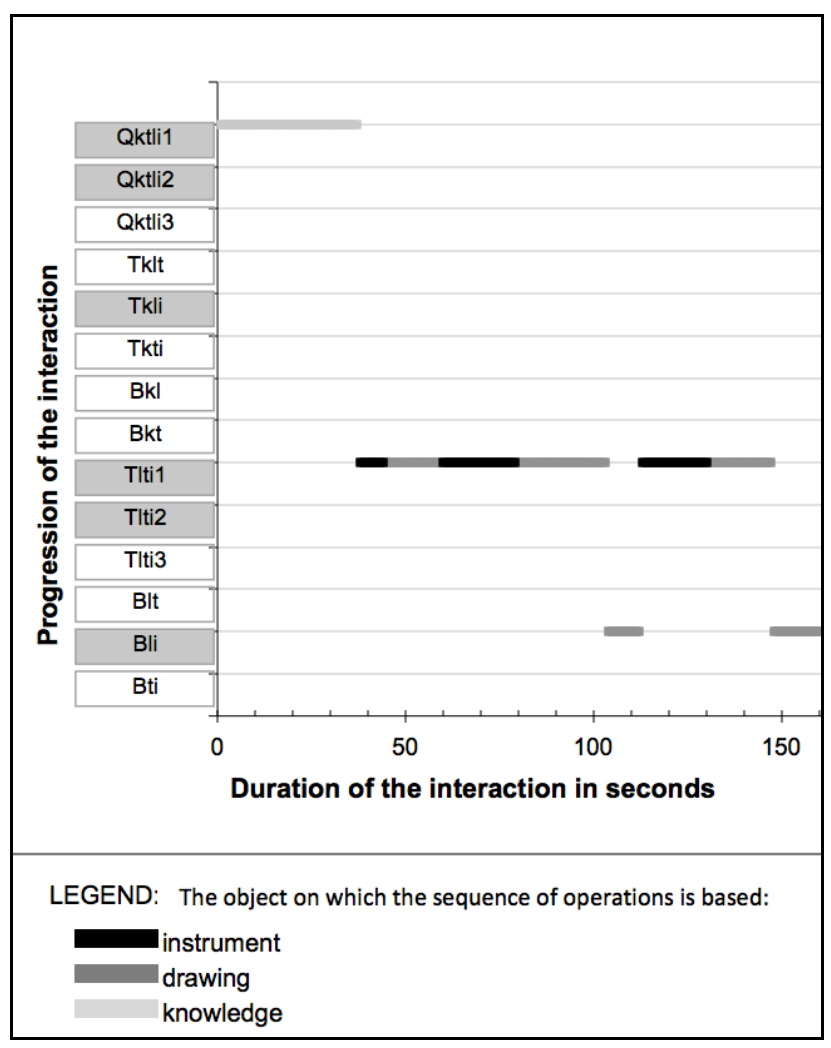

Figure 12. Dyad 2, Extract from the timeline showing the exchanges between the minutes 00 and 03

Developed in this way, the diagrams enable us to obtain an overall view of the characteristics of interactions, in terms of the different configuration codes of the Media Square such as:

- information content of exchanges (Are they based on the knowledge involved? The operation of the instrument such as the device? Or the drawing activity?);

- the author of the manipulations (Does the child handle the simulator? Or the parent? Or both?);

- the discursive and/or manipulative exchanges (Do the exchanges occur as discussion and as manipulation of the computer (instrument) simultaneously? Or just discussion between the parent and the child? Or only handling the computer (the instrument)?).

As such, the diagrams of the "parent" group have provided a comparative analysis of interactions between the ten adult/child dyads.

The advantage of these diagrams is that they provide a visual record of all characteristics of interactions according to: a) their chronological order, b) their similarities from one interaction to another, c) specificities of differences according to the criteria defined as research objectives. 


\subsection{The KITLoK (Knowledge, Instrument, Tutor, Learner, other Knowledge) Model}

The KITLoK (Knowledge, Instrument, Tutor, Learner, other Knowledge) model, proposed by Ailincai in 2010 [3], is based partly on Vygotsky's theory, and on the works of Bruner., From this viewpoint culture provides the child with all of the basics for his/her cognitive development; According to Bruner, the development of intelligence is closely linked to the construction of intentional behavior, since intentions are linked to culture $([7,42])$.

Interaction plays a central role in this model which has been tested in the analysis of varied didactic situations:

- diversity of contexts: in a museum, school or family setting, - diversity in the age of students/children: students at primary or secondary school level;

- variety in the size of groups: two parties interacting, small groups or the whole of the class ;

- linguistic and cultural diversity;

- diversity of the learning situations: tutoring (teacher/student; parent/child; student/student) or learning mediated by a computer.

Inspired by Bernard's Media Square, the KITLoK model offers to represent interactions in a polyadic context.

Analysis methods of polyadic educational models are mainly used for studying situations arising in school (Bucheton's “multi-agenda” model, [8]; Altet's systemic model [4]; Legendre's SOMA model [23], Reseau's Pedagogical Square [35], to name just a few). However, given the fact that we do not evolve in the school context, we have had to take into account the specificities and requirements of the museum context.

Firstly, the learning contract which links the student and teacher in school is not explicit regarding the media field. The child/student who visits the exhibition is free to move around and is not subject to a visiting schedule or specific objectives in terms of success and so forth. The activity is therefore not predetermined. The child handles the museum devices for a period that is not fixed in advance and can vary according to different factors:

- internal factors (the child's interest in handling the device, fatigue, different physiological needs, etc.);

- external factors (the desire of the accompanying adult to either see the child continue handling the item or otherwise oblige them to continue the visit, the end of the tour, an animation which is starting, etc.).

The author places all of these factors together as "determinants of the media situation".

Secondly, in contrast to the school environment in which the teacher knows and controls the instruments he uses with students, in the museum context, the adult does not know a priori the museum items that he actually discovers at the same time as the child he accompanies. Furthermore, despite the written instructions accompanying the devices, no operating rules are imposed, with the designer (sender) having no control over the visitors (receivers).

Whilst retaining the basic building blocks of the Media Square (Tutor/Learner/Instrument/Knowledge), the KITLoK model (see Figure 13) goes further in the analysis of interactional dynamics, by proposing:

- the identification of simultaneous interactive situations, by duplicating the depiction of the interactive situation: in the " $n+1$ " space, the diagram represents all of the exchanges in which the tutor participates, whilst in the "n-1" space, the diagram represents the exchanges which take place between learners only, excluding the tutor. These two interactive situations can function simultaneously with the pupils interacting with each other whilst the tutor interacts with the group;

- the identification, in the "n" space, of noteworthy behavior of the students (joint attention, collective response, lack of attention or disciplinary problems) may impact the interactional structure.

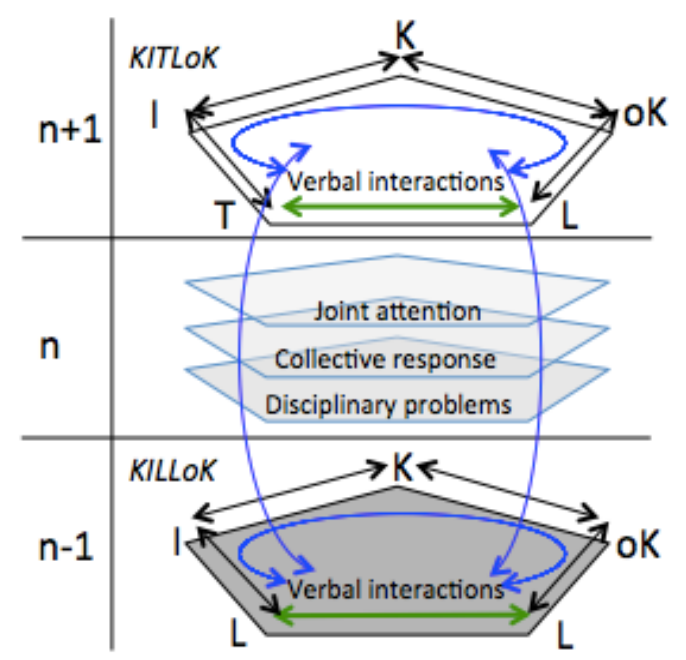

Figure 13. KITLoK Model (Ailincai, 2010)

The model also proposes a new pole entitled "other Knowledge" (hereafter oK), which is not a misappropriation of the instrument as Rabardel describes, but refers to spontaneous knowledge which can impose itself through the development of the interaction and is unrelated to the Knowledge $(\mathrm{K})$ targeted by the learning situation (for example, questions and/or information expressed by learners which are not related to the activity; "gaps" linked to cultural and language determinants, etc.).

Moreover, oK could refer to a second objective of the activity. For example, in the case of activities using the Content and Language Integrated Learning( CLIL) approach, the professor aims for both the acquisition of disciplinary knowledge (which could be called "knowledge at stake") and knowledge related to the acquisition of the foreign language in use (which might be called “other knowledge”) (see Gabillon \& Ailincai, 2012)

The model presented in Figure 13 shows all of the interactive situations operating simultaneously. This situation is one possibility. Like in Bernard's Media Square the KITLoK model can be truncated (solely certain poles might be in interaction with one another). Moreover, the specificities linked to the museum context (cited previously) can sometimes provoke some direct relations between two poles (binary relations):

"learner/instrument" and "tutor/instrument" interactions which are binary human/machine communications, i.e. functional interactivity [5];

- direct verbal or non-verbal "tutor/learner" interactions which can take place without the use of the neither the instrument or knowledge;

- direct "learner/knowledge" and "tutor/knowledge" interactions which describe cognitive engagement of the human interactant with the knowledge in question. (this is 
the knowledge aimed for by the designers of the instrument).

These binary interactions combine in the ternary and quaternary systems based on the number of parties involved and the knowledge discussed. In the KITLoK model, these different systems can, in turn, interact with each other depending on the initiators of the exchanges, or the object of the exchanges, and so forth. The more the poles interact, the richer the exchanges and the fuller the models operate.

The use of the KITLoK model to analyze the interactional variation of a teaching-learning session highlights many possible variations depending on the "parties" mobilized. The different configurations and coded information are shown in Table 3.

Table 3. The KITLoK coding grid

\begin{tabular}{|c|c|c|}
\hline Code & Detailed Code & Characteristic of the exchange \\
\hline \multicolumn{3}{|c|}{$\mathbf{n}+1$ : Interactions including the tutor (or initiated by the tutor) - KITLoK } \\
\hline KITLoK & $\begin{array}{l}\text { Knowledge in action-Instrument-Tutor-Learner- } \\
\text { other Knowledge }\end{array}$ & $\begin{array}{l}\text { The model is only complete in activities targeting two "knowledges" (e.g. the } \\
\text { CLIL approach referred to above) }\end{array}$ \\
\hline KITL & Knowledge in action-Instrument-Tutor-Learner & $\begin{array}{l}\text { The exchange (and/or manipulation) concerns the Knowledge in action and either } \\
\text { refers to or uses the instrument }\end{array}$ \\
\hline ITLoK & Instrument-Tutor-Learner-other Knowledge & $\begin{array}{l}\text { The exchange (and/or manipulation) concerns other Knowledge and either refers } \\
\text { to or uses the instrument }\end{array}$ \\
\hline KTL & Tutor-Learner-Knowledge in action & $\begin{array}{l}\text { The exchange (or gesture) concerns the Knowledge in action without using or } \\
\text { referring to the instrument }\end{array}$ \\
\hline ITL & Instrument-Tutor-Learner- & $\begin{array}{l}\text { The exchange and/or manipulation of the instrument without reference to any } \\
\text { kind of Knowledge, or the misappropriation of the instrument }\end{array}$ \\
\hline TLoK & Tutor-Learner-other Knowledge & $\begin{array}{l}\text { The exchange (and/or manipulation) between the Tutor and the Learner concerns } \\
\text { other Knowledge }\end{array}$ \\
\hline KIT & Knowledge in action-Instrument-Tutor & $\begin{array}{l}\text { The Learner is absent; the Tutor acts alone on the instrument in relation to the } \\
\text { Knowledge in action }\end{array}$ \\
\hline IToK & Instrument-Tutor-other Knowledge & $\begin{array}{l}\text { The Learner is absent; the Tutor acts alone on the instrument in relation to another } \\
\text { knowledge }\end{array}$ \\
\hline KT & Knowledge in action-Tutor & The Learner is absent; the Tutor is preoccupied by the Knowledge in action \\
\hline ToK & Tutor-other Knowledge & The Learner is absent; the Tutor is preoccupied by other Knowledge \\
\hline IT & Instrument-Tutor & $\begin{array}{l}\text { The Learner is absent; the Tutor uses the instrument without a specific purpose in } \\
\text { mind or without aiming for any kind of knowledge }\end{array}$ \\
\hline \multicolumn{3}{|c|}{ n : Behavior of the interactants which either characterizes some interaction time or is liable to change the interaction } \\
\hline JA & Joint Attention & Learners observe a phenomenon in order to have a response \\
\hline CR & Collective Response & Several learners respond to the tutor's requests. \\
\hline AA & Absence of attention & $\begin{array}{l}\text { Learners respond noisily, disturbing the activity and/or interrupting the interaction } \\
\text { linked to knowledge. }\end{array}$ \\
\hline \multicolumn{3}{|c|}{ n -1:Interactions amongst learners $-\mathbf{K I L L o K}$} \\
\hline IL & Instrument-Learner & $\begin{array}{l}\text { Learners use the instrument individually without collaborating or targeting any } \\
\text { particular knowledge }\end{array}$ \\
\hline LoK & Learner-other Knowledge & $\begin{array}{l}\text { Learners act individually (without collaborating), concerning other knowledge or } \\
\text { other activity }\end{array}$ \\
\hline KL & Knowledge in action-Learner & $\begin{array}{l}\text { Learners act individually (without collaborating) but remain preoccupied by the } \\
\text { knowledge in action }\end{array}$ \\
\hline ILoK & Instrument-Learner-other Knowledge & $\begin{array}{l}\text { Learners use the instrument individually (without communicating between } \\
\text { themselves) concerning other Knowledge }\end{array}$ \\
\hline KIL & Knowledge in action-Instrument-Learner & $\begin{array}{l}\text { Learners work individually without communicating between themselves but } \\
\text { remain preoccupied by the knowledge in action and use the instrument }\end{array}$ \\
\hline LLoK & Learner-Learner-other Knowledge & Learners exchange between themselves on other Knowledge \\
\hline ILL & Instrument-Learner-Learner & $\begin{array}{l}\text { Learners discuss the instrument (or handle it) with little concern for the } \\
\text { Knowledge in action }\end{array}$ \\
\hline KLL & Knowledge in action-Learner-Learner & $\begin{array}{l}\text { Learners discuss amongst themselves the Knowledge in action; the Instrument is } \\
\text { absent }\end{array}$ \\
\hline ILLoK & Instrument-Learner-Learner-other Knowledge & Learners use the instrument regarding other Knowledge. \\
\hline KILL & Knowledge in action-Instrument-Learner-Learner & Learners exchange on the knowledge in action by using the instrument \\
\hline KILLoK & $\begin{array}{l}\text { Knowledge in action-Instrument-Learner-Learner- } \\
\text { other Knowledge }\end{array}$ & $\begin{array}{l}\text { The model is only complete in activities targeting two types of "knowledge", e.g. } \\
\text { the CLIL approach: students discuss amongst themselves the knowledge at stake } \\
\text { ("K"), in a foreign language ("oK") }\end{array}$ \\
\hline
\end{tabular}

As in Bernard's model, the KITLoK coding grid is consistent with qualitative research. The video recording and transcription of the situation studied are indispensable. The coding of the transcribed corpus provides a detailed analysis of the learning situation. Compared to the previous model, which analyzes the sequence as a whole, the KITLoK model is used for coding the constituent of each exchange of the sequence (see Figure 14).

We define exchange here as being the smallest unit of interaction composed of verbal and/or non-verbal interventions.
Depending on the number of interventions, which constitute it, an exchange can be: limited (if composed of two interventions), extended (if there are more than three components) or truncated (when an intervention is not taken into account by the other interlocutor; that is, if an intervention does not receive a verbal or non-verbal reaction) [22]. For this type of analysis, activities must be filmed and then transcribed. The following table (see Table 4) shows a concrete example of the transcription and coding of a teaching/learning session. The extract is taken from a science activity that took place in an 
exhibition called "Butterfly Greenhouse" in the Cité des Sciences et de l'Industrie in Paris), with a group of CE2 students $(n=7)$ (in the second year of elementary class, the equivalent of Third Grade). The knowledge at stake here was the discovery of the life cycle of butterflies.

We briefly present the museum element in which the observation of interactions occurred.

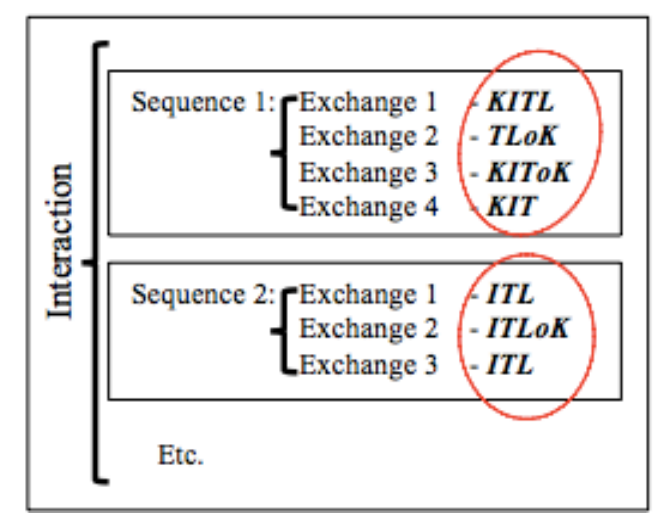

Figure 14. Synthetic example of coding of the corpus using the KITLoK grid

\subsubsection{Presentation of the "Butterfly Greenhouse" media device"}

The educational museum item, "the Butterfly Greenhouse", identified in the exhibition literature as an island, is a real "micro-world" as Paour calls it. A tropical greenhouse was installed in part of the exhibition called “The Garden” (see Figure 15).

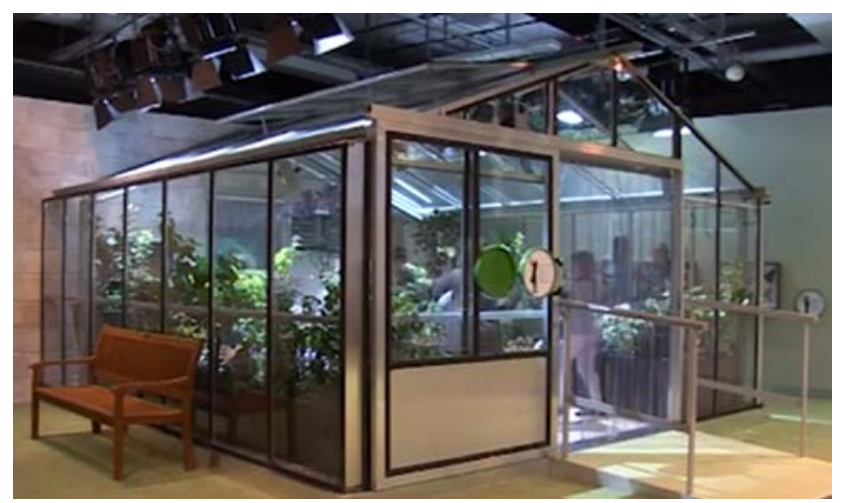

Figure 15. The museological item "the Butterfly Greenhouse" in the exhibition for 5-12 year-olds at the Cité des Enfants

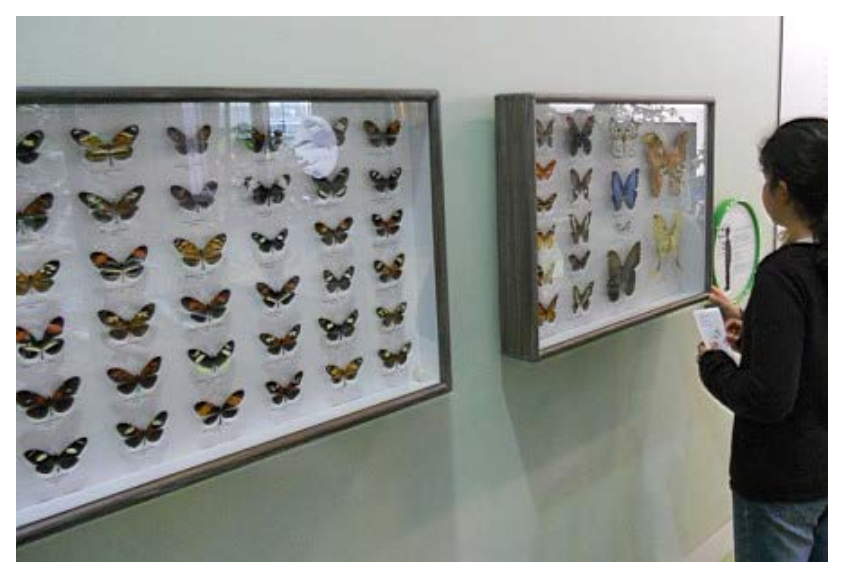

Figure 16. Display case showing the variety of butterflies

The habitat of tropical butterflies enabled us to observe the behavior of butterflies in their natural environment and discover the different life stages of a butterfly (egg, caterpillar, chrysalis and butterfly). This island consists of several educational museum elements: display cabinets exhibiting the diversity of butterflies and specimens within the same insect family (including Heliconius, as well as moths and butterflies, tropical species, species from temperate regions) (see Figure 16).

Other display cabinets show the pupae very closely and reveal a specific stage of development of a chrysalis. A film shows the accelerated different developmental stages of a butterfly and thus enables us to discover the development cycle of this insect.

\subsubsection{Presentation of the "Butterfly Greenhouse" media device”}

The group of seven students we observed remained in the greenhouse for 11 minutes and received tutoring from their teacher. A transcribed extract which portrays the identified exchanges and their coding is presented in Table 4. The first analysis (see Column 3 of Table 4), depending on the type of exchanges constituting the activity, provides us with information on the quality of the interactions.

For example, the presence of extended exchanges can indicate: a) participation of the students; b) their interest in the knowledge proposed by the tutor (via requests for clarifications which lengthen the exchange);c) their ability to become involved in the tasks that they have been set (through answers and follow-up or complementary information that they can provide); d) understanding of the subject, and so forth.

A limited exchange can demonstrate the need for sustained tutoring from adults (question/answer).

A significant number of truncated exchanges could suggest: a) a lack of understanding of the tutor's explanations/instructions b) a lack of interest in the set topic, and so forth.

The second analysis based on KITLoK coding model (see Column 4 of Table 4) provides us with detailed information on the content of the exchanges.

The coding analysis can be presented in the form of a timeline that provides an overview of the quality of exchanges between the interactants (presence of the knowledge being targeted; student participation, use of artifacts, etc.).

In Figure 17 we present such an example of a timeline. The KITLoK codes are located on the vertical $\mathrm{Y}$ ordinate axis. The horizontal $\mathrm{X}$ abscissa axis indicates time in seconds. The results presented in the timeline indicate the type of exchange corresponding to the time of the activity.

The timeline is automatically generated from an Excel file (once the values for each code have been added).

This type of coding, even though time-consuming, provides rich information about the elements of polyadic interactions for learning, such as:

- the presence of relevant knowledge $(\mathrm{K})$, or other knowledge (oK), or different exchange types;

- the presence of the instrument and how it is used;

- the type of learning situation (collaborative or not);

- the number of interactants (didactic situation or polyadic, including in the classroom);

- the initiator of the exchange (the tutor, the learner);

- the space opened by the multiple and simultaneous interactions (learner-computer / tutor-computer / tutor- 
learner); this multi-interactional space is analyzed in the diagram to visualize all the interactions that take place at a given time (for example, there may be an interaction initiated by the professor and other interactions initiated by the students).
Furthermore, the specificity of the KITLoK model consists in the fact that it enables us to consider exchanges taking place simultaneously: on one side, between students, and, on the other side, between the teacher and another group of students.

Table 4.Example of the coding of an extract from the transcriptions: breaking down and coding the exchanges with the KITLoK model

\begin{tabular}{|c|c|c|c|}
\hline Time & Transcription of the Professor-Student exchanges & Type of exchange & Content according to KITLoK \\
\hline \multirow[t]{2}{*}{$35 ’ 47$} & Professor: Look with the magnifying glass and tell me what you see on the leaf & \multirow{2}{*}{ Limited exchange } & \multirow{2}{*}{ KITL } \\
\hline & Paul: It looks like eggs & & \\
\hline \multirow[t]{5}{*}{$37 ’ 15$} & Professor: We are now going to look very closely at the leaves of this plant... & \multirow{10}{*}{ Extended exchange } & \multirow{10}{*}{ KITL } \\
\hline & Anne: I can see a sort of ... like a "scab”? & & \\
\hline & Tom: A “dropping”? (Laughing) & & \\
\hline & Anne: a SCAB!! & & \\
\hline & Jean: But no Miss! I know, me! They are “cocoons” & & \\
\hline \multirow[t]{3}{*}{$38 ’ 10$} & Marc: Yes, they are for butterflies & & \\
\hline & Marie: For eggs, not for butterflies! & & \\
\hline & Jean: But no, there is a worm inside! To make butterflies & & \\
\hline \multirow[t]{2}{*}{ 38’58 } & Professor: Yes, very good... it's called a chrysalis or a cocoon & & \\
\hline & Jean: I was right! & & \\
\hline \multirow[t]{3}{*}{ 39’12 } & Marie: Miss, are there eggs inside? & \multirow{3}{*}{ Limited exchange } & \multirow{3}{*}{ KITL } \\
\hline & Professor: there is a caterpillar inside & & \\
\hline & Jean: Yes!!! & & \\
\hline $40 ’ 00$ & $\begin{array}{l}\text { Professor: Now if we go over to the other side of the greenhouse (moving } \\
\text { towards another window) }\end{array}$ & Truncated exchange & \multirow[t]{2}{*}{ TK } \\
\hline $40 ’ 50$ & The group of students ignore the instruction and remain around the chrysalises & & \\
\hline
\end{tabular}

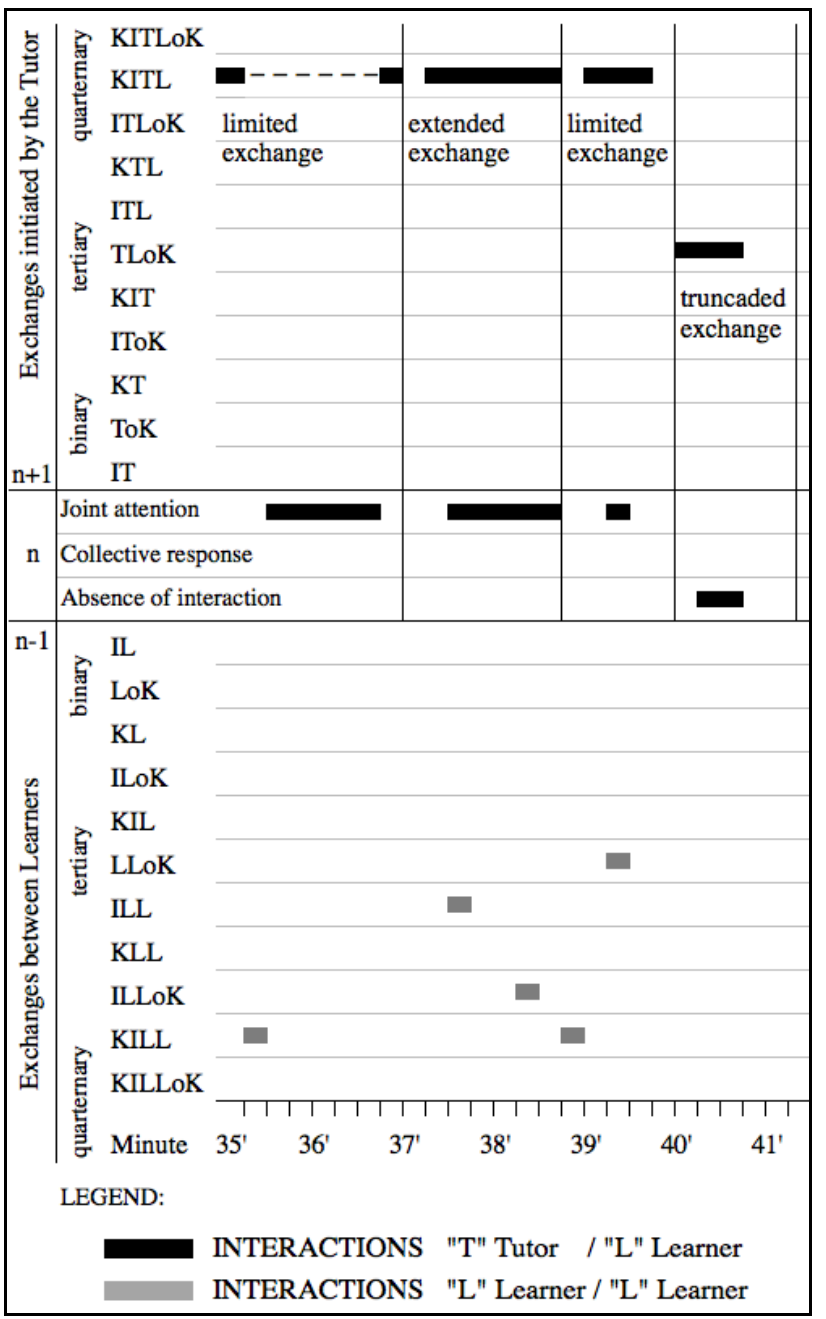

Figure 17. Extract from the timeline showing the exchanges between the minutes 35 and 41 of the "butterfly cycle" activity

\section{Conclusion}

In this article we briefly introduced two educational interaction analysis models designed for informal educational settings namely a scientific and technical exhibition in the Cité des Enfants, part of the Cité des Sciences et de l'Industrie in Paris. The first model, the Media Square of Bernard [6] was designed as part of his doctoral thesis whilst studying dyadic interactions (parent/child) for educational purposes and used a simulation software for color mixing. The second educational interaction analysis model, Ailincai's KITLoK model [3], was inspired by Bernard's model but aimed at responding to the need to account for polyadic interactions (a group of students/teacher) around an exhibit that allowed several parties to be involved.

The choice of these models is justified by their particularity, including the consideration of the two mediations that intervene between the learner and the knowledge: the human mediator (parent/teacher/museum professional) and the technical mediator (a specific museological device/a "micro-world" like the "butterfly greenhouse"/handling/experiments/media, film, audio, software/various educational games).

Indeed, the majority of research conducted at the Cité des Enfants looked into human interactions and the supervision carried out by adults accompanying children and showed no interest in the museum items as educational interaction tools. The instrumental dimension of these technical/educational tools is usually not reflected in the observations made. We believe that the visitors' interactions and behavior are directly influenced if they face difficulties in understanding how an instrument/tool works. In the two models we presented in this paper we considered the instrument as an integral element of an 
interaction. On this basis, we proposed interaction analysis models integrating poles representing the child, adult, instrument and knowledge.

Pertaining to the results obtained, these two models proved to be rather consistent. By isolating human mediation from instrumental mediation; and by separating the instrument, (the technical object) from the knowledge mediated by this instrument, we were able to distinguish 14 different configurations using the Media Square model and 23 configurations using the KITLoK model and were able to view the relationships between the components of the media situation: the learner, tutor, knowledge, instrument and other knowledge. To analyze the data the transcripts of the recorded exchanges (both verbal and non-verbal levels), were framed into sequences. The coding of these sequences using coding grids (from the respective model configurations) enabled us to develop a diagram for each interaction. These diagrams allowed us to characterize the interactions using the criteria we established to observe the behavioral patterns of the tutors during their interactions, to view these exchanges in terms of their informational content or, in terms of learner participation while handling the instruments or even the nature of the exchanges (discursive and /or manipulative).

The interest in these two analysis models lies in the fact that the coding grids and simplified grouping codes used for analysis provide an interesting means to measure the impact of the use of media tools amongst children accompanied by adults, based solely on the observation of interactions.

\section{References}

[1] Ailincai, R., Caillot, M. and Weil-Barais, A. "De l'étude des interactions parents/enfants dans un contexte muséal scientifique à une proposition d'intervention innovante auprès des parents", in Les quatrièmes rencontres de l'ARDIST, INRP, Lyon, 2005, 5-12.

[2] Ailincai, R. Un dispositif d'éducation parentale. Sensibilisation des parents à leur rôle d'accompagnateur de leur enfant dans le cadre d'un musée à caractère scientifique et technique. Thèse de doctorat, Université Paris Descartes, 2005.

[3] Ailincai, R., "Interactions éducatives en contexte plurilingue et multiculturel”, in Congrès Mondial de Linguistique Française, CMLF 2010, Didactique et enseignement, français langue maternelle, français langue seconde, Neveu F, Muni Toke V, Durand J, Klingler T, Mondada L, Prévost S, Institut de Linguistique Française, Paris, 2010.

[4] Altet, M., Les pédagogies de l'apprentissage, Presses Universitaires de France, Paris, 1997.

[5] Barchechath, E. and Pouts-Lajus, S. "Sur l'interactivité" postface, in K., Crossley and L., Green. Le design des didacticiels. Paris: OTE (Observatoire des Technologies pour l'Éducation en Europe), 1990.

[6] Bernard, F-X., L'impact cognitif des dispositifs médiatiques sur les enfants d'âge préscolaire en situation d'apprentissage avec un adulte: Étude d'un cas de simulateur informatique dans le contexte d'une exposition scientifique, Thèse de doctorat, Université Paris Descartes, 2006.

[7] Bruner, J. S., Acts of Meaning, Harvard University Press, 1990.

[8] Bucheton, D., L'agir enseignant: des gestes professionnels ajustés, Toulouse: Octares, 2009.

[9] Chaumier, S., Casanova, L., and Habib, M-C., Les accompagnateurs de la Cité des Enfants, Rapport d'étude soumis au Département Évaluation et prospective, Cité des Sciences et de l'Industrie, Paris, 1995.

[10] Département Cité des Enfants, Parcours Parents. Cité des Sciences et de l'Industrie. Paris, 1999.

[11] Giordan, A., and De Vecchi, G., Les origines du savoir. Des conceptions des apprenants aux conceptions scientifiques. Neuchâtel-Paris: Delachaux and Niestlé, 1987.
[12] Giordan, A., "De la catégorisation des conceptions des apprenants à un environnement didactique "optimal". Protée, 16, (3), 23-52. Québec, Expo-Média, 1988.

[13] Giordan, A. "Repenser le musée à partir de comprendre et d'apprendre“", in B., Schiele, and E., Koster, (Eds.), La révolution de la muséologie des sciences: Vers les musées du XXI siècle? Lyon : Presses Universitaires de Lyon, 1998, 187-205.

[14] Giordan, A., Une didactique pour les sciences expérimentales. Paris: Belin, 1999.

[15] Guichard, J., Représentations des enfants à propos des fourmis et conception d'un outil muséologique, Aster, 6, Paris: INRP, 1988, 213-236.

[16] Guichard, J., Diagnostique didactique pour la production d'un objet muséologique. Thèse de doctorat. Université de Genève, 1990.

[17] Guichard, J., La prise en compte du visiteur comme outil de la conception muséologique: un exemple concret, la Cité des Enfants. Public et musées, 3, 1993, 111-135.

[18] Guichard, J., “Adapter la muséologie aux enfants“, in B., Schiele, and E., Koster, (Eds.), La révolution de la muséologie des sciences: Vers les musées du XXI ${ }^{e}$ siècle ?. Lyon : Presses Universitaires de Lyon, 1998, 207-248.

[19] Guichard, J. and Martinand J.L., Médiatique des sciences, Paris: Presses Universitaires de France, 2000.

[20] Houssaye, J., Le triangle pédagogique. Peter Lang, Berne, 1988.

[21] Houssaye, J. "On the relevance of the pedagogical triangle: understanding the rules of functioning of the pedagogical situation," Congress American Educational Research Association, La Nouvelle Orleans, 1994.

[22] Kerbrat-Orecchioni, C., Les interactions verbales, tome1, Paris : Armand Colin, 1998.

[23] Legendre, R., Dictionnaire actuel de l'éducation, Larousse, Paris \& Montréal, 1988.

[24] Martinand, J.L., "Pratiques de référence, transposition didactique et savoirs professionnels en sciences et techniques“, Les sciences de l'éducation, 2. 23-29. 1989.

[25] Morice, A., Intégration d'infrastructures extra-scolaires dans l'apprentissage des sciences et de technologie à l'école primaire : l'Inventorium. Rapport de recherche soumis au Département Évaluation et Prospective, Cité des Sciences et de l'Industrie, Paris, 1987.

[26] Natali, J. P. and Martinand, J. L., "Une exposition scientifique thématique. Est-ce bien concevable “ Éducation Permanente, 90. 115-129. 1987.

[27] Paour, J. L., "Quelques principes fondateurs de l'éducation cognitive“, Interactions didactiques, 8, 45-52. 1988.

[28] Paour, J.L. Un modèle cognitif et développemental du retard mental pour comprendre et intervenir. Thèse de doctorat. Université de Provence, 1991.

[29] Pourtois, J.-P., Comment les mères enseignent à leur enfant. Paris, Presses Universitaires de France, 1979.

[30] Piani, J. and Weil-Barais, A. "Comment les parents accompagnent-ils leurs enfants dans la découverte des sciences et des techniques dans un musée ?”, in A. Dumas Carré and A. WeilBarais (Eds.), Tutelle et médiation dans l'éducation scientifique. 251-267. Berne: Peter Lang, 1998.

[31] Rabardel, P. and Vérillon, P., "Relation aux objets et développement cognitif“, in A. Giordan, and J.-L. Martinand (Éds.), Communication, éducation et culture scientifiques et industrielles. Actes des 7èmes Journées internationales sur l'éducation scientifique. 395-399. Paris : Université Paris 7. 1985.

[32] Rabardel, P., "Micro-genèse et fonctionalité des représentations dans une activité avec instrument", in A. Weil-Fassina, P. Rabardel and D. Dubois (Éds.), Représentations pour l'action. 113-117. Toulouse: Octares. 1993.

[33] Rabardel, P., Les hommes et les technologies: Approches cognitives des instruments contemporains, Armand Colin, Paris, 1995.

[34] Rabardel, P. and Bourmaud, G., "From computer to instrument system: a developmental perspective," Interacting with Computers 15(5). 665-691. 2003.

[35] Rézeau, J., Médiatisation et médiation pédagogique dans un environnement multimédia. Le cas de l'apprentissage de l'anglais en Histoire de l'art à l'Université, Thèse de doctorat, Université Bordeaux II. Non publié. 2001.

[36] Romano, S., L'espace 3-5 ans de la Cité des Enfants: comportements de visite et points de vue d'un échantillon d'enfants et de leur parents sur les unités d'exposition. Rapport de 
recherche soumis au Département Évaluation et prospective, Cité des Sciences et de l'Industrie. Paris, 1999.

[37] Samuels-Pitzini, A. and Cauzinille-Marmeche, E., Interactivité et interactions humaines: quelles interventions à quel moment?, Rapport de recherche soumis au Département Évaluation et prospective, Cité des Sciences et de l’Industrie. Paris. 1996.

[38] Vygotsky, L.S., Thought and language. MIT press, 1934/2012.

[39] Weil-Barais, A., and Piani, J., Les échanges adultes-enfants à la Cité des Enfants. Rapport de recherche soumis au Département Évaluation et prospective, Cité des Sciences et de l'Industrie. Paris, 1993.
[40] Weil-Barais, A., and Piani, J., Les conditions de coéducation pour des visiteurs ne venant pas spontanément à la Cité des Enfants. Rapport de recherche soumis au Département Évaluation et prospective, Cité des Sciences et de l’Industrie, Paris, 1995.

[41] Weil-Barais, A. and Dumas-Carré, A., "Les interactions didactiques: tutelle et/ou médiation?”, in A. Dumas-Carré and A. Weil-Barais (Eds.), Tutelle et médiation dans l'éducation scientifique. 1-15. Berne: Peter Lang, 1998.

[42] Wood, D., Bruner, J. S., and Ross, G., "The role of tutoring in problem solving,” Journal of Child Psychology \& Psychiatry \& Allied Disciplines, 17(2). 1976. 89-100. 